\title{
Brief account on the head injury of a noble youngster in the sixteenth century (Prince Don Carlos, heir to Philip II of Spain, 1545-1568)
}

\author{
Juan F. Martínez-Lage ${ }^{1}$. Claudio Piqueras-Pérez ${ }^{1}$
}

Received: 13 March 2015 / Accepted: 23 March 2015 /Published online: 3 April 2015

(C) Springer-Verlag Berlin Heidelberg 2015

\section{Introduction}

Some traumatic events, among them head injuries, are occasionally reported in the medical literature to illustrate relevant affairs that sometimes modify the course of the history [7, 8, 14]. Some of these incidents involve persons of royal lineage, as happened with King Henry II of France who suffered a penetrating orbital injury complicated by a brain contusion and an intracranial empyema that caused the King's death [7, 14]. In addition to the historical interest that these traumatisms arise, they undoubtedly provide an occasion to review the level of the medical practice in a determined epoch. For this purpose, we retrospectively surveyed the events regarding the unfortunate life of Prince Don Carlos, first-born son and heir to King Philip II of Spain, whose infancy and adolescence were plagued with a multitude of medical troubles including inherited traits, recurrent bouts of malaria, and finally, the deadly complications of a seemingly trivial head injury $[4,8,11$, 12]. The descriptions regarding Don Carlos' skull trauma have been documented from the official medical reports of doctors Olivares and Daza Chacon and from the brief English account of the accident written by Thomas Chaloner, ambassador of her majesty the Queen Elizabeth of England [4, 8, 11].

Juan F. Martínez-Lage

juanf.martinezlage@gmail.com

1 Regional Service of Neurosurgery, Virgen de la Arrixaca University Hospital, 30120 El Palmar, Murcia, Spain

\section{Don Carlos' case report}

On 19 April 1562, a 17-year-old boy, Prince Don Carlos of Asturias, suffered a blow on the back of his head when he fell down five steps of a stairway while he was running after a young maid. Due to the strong impact against a closed door, he sustained a scalp laceration on his left occipital region, but he did not lose consciousness. The surgeon Daza Chacon was called upon to examine Don Carlos in the presence of the Prince's personal physicians, doctors Olivares and Vega. The wound had "the size of a thumb's fingernail encircled by an area of contused scalp," becoming the pericranium visible, which appeared contused too. Daza Chacon cured the wound that caused much pain to the royal patient. The master of the King's horses, Luis Quixada, recommended the surgeon "do not treat his highness as a Prince but as a common person."

Don Carlos was immediately put to bed and started copious sweating that avoided performing a bloodletting. The King who resided in Madrid was immediately notified of the facts and dispatched Doctor Juan Gutierrez, his chamber physician, together with the surgeons Portugues and Pedro de Torres, to Alcalá where the Prince had been sent for treatment of quartan fever and also for initiating studies in Alcalá University.

On the 4th day after the fall, the patient remained febrile and exhibited swollen and painful lymphatic nodes at his neck. He also complained of numbness in his right leg similar to the one felt during his previous episodes of quartan fever. All these symptoms subsequently subsided but returned the 10th day after the traumatism. His highness himself observed that "fever and a head wound are signs of a bad presage." On the 11th day, a clinical meeting involving a troupe of physicians was held. Differential diagnosis was established against an inner lesion or "a pericranial or skull infection with 
retained fragments and purulent material." Initially, most physicians and surgeons kept a conservative and prudent attitude, perhaps owing to the category of their royal patient. The Bachelor Torres (Daza-Chacon's teacher) was also called on consultation and suggested skull curetting.

The six attending physicians took the determination of surgically exploring the scalp wound to enlarge its opening as the wound lips had already closed trapping inside a considerable amount of material. On 1 May, the wound was cleaned in the presence of Doctor Andrea Vesalius. During the following days, a large subcutaneous collection appeared that progressively involved the patient's head, neck, and upper trunk, which was accompanied by an erysipelatous scalp reaction. Doctors Vesalius and Portugues considered that the main damage was inside the skull and that there was no other option than to perforate it for reaching the "brain clothing" (meningeal coverings). Daza Chacon and other colleagues discussed two diagnostic possibilities: a pericranial and osseous infection or that the infection had penetrated the skull sutures reaching the cerebral coverings, although the brain itself was apparently spared. In the meantime, the Prince continued experiencing occasional numbness in his right leg and fits of delirium.

After much debate, in the morning of 21 May, Doctor Portugues started the curettage of the skull, although, due to certain surgical inexperience noted by the Duke of Alba, Daza Chacon trephined "until the bone appeared white and sound" and until the bleeding convinced them that there was no need for further surgery [4]. According to the official physicians' reports, no skull fracture was found during the repeated surgical explorations of the wound, but on the contrary, skull osteitis and intracranial empyema were considered in the diagnosis [9]. During the following days, the Prince's eyelids became closed by orbital cellulitis that required surgical evacuation in several occasions. The patient's general condition was very poor indeed despite administering general therapies and local remedies, such as diverse syrups, powders, plasters, ointments, and herbal preparations.

On 2 June 1562, a bone sequestrum together with some debris came out during wound cleaning. In the ensuing days, the Prince started to recover and was declared cured on July 13 1562, after 93 days of treatment. The physicians and surgeons who had taken care of him left Alcalá.

The Prince's gloomy prognosis led to considering him twice left for dead. Other remedies were also taken into account for achieving the Prince's recovery as were solemn and frequent processions of all religious orders with the images of our Lady and Saints. Relics were also applied to the wound. Even the corpse of a saint, Fray Diego de Alcalá, was laid by Don Carlos' bed. Chaloner, the English ambassador, ironically stated: "now I believe that God's minister, nature, hath in despite of surgeons' inconsiderate dealing, done more for the Prince than they were aware of" [8].

\section{Past and personal history of Don Carlos}

Don Carlos (1545-1568) was the eldest son of King Philip II of Spain, and his heir apparent $[1,2]$. He was also known as Carlos Prince of Asturias, a title hold by all the heirs to the throne of Spain. Don Carlos was born in Valladolid on 8 July 1545. Infante's mother, María Manuela de Portugal, died 4 days after parturition. During his first 4 years of life, the Prince was nurtured and educated by close relatives and personnel of the Court given that his father, King Philip II of Spain, had to reside in the Low Countries. The Prince had a frail physical constitution showing an asymmetry of both shoulders and a leg discrepancy together with spinal lordosis, not shown in his paintings (Figs. 1 and 2) [4, 8, 10-12]. He also showed signs of psychological instability and of misconduct. Probably, these psychophysical problems were related to frequent inbreeding among the Prince's ancestors pertaining to the Habsburg dynasty and the royal families of Portugal and Spain [2].

At the age of 14 years (Fig. 1a, cover picture, Fig. 1b), and from 1559 to 1561, the Prince suffered from malaria (quartan fevers) and was sent from Madrid to Alcalá in search of a favorable climate [4, 10-12]. His grandfather, Emperor Carlos V, had also suffered from this disease as has been confirmed by a microscopic study of the Emperor's remnants [5]. Doctor Cristobal de Vega, formerly in charge of a chair at the University Medical School, was designated as personal physician and mentor of the Prince [10]. In the year 1560 , Don Carlos was proclaimed heir to the throne of Castile and 3 years later as heir apparent to the crown of Aragon too [1,2]. During his adolescence and early youth (Fig. 2), Don Carlos showed a bizarre and aggressive behavior in many occasions that motivated that his father, King Philip II, abandoned the idea of considering him as his successor $[1,2,4,6,12]$.

The Prince's conduct was greatly worsened after his head trauma. He demonstrated an insane aversion towards his father and towards the Duke of Alba. He even attempted to join the revolt of the Low Countries against the Spanish crown and manifested his intention of killing the King [1, 2, 4, 6, 12]. On 17 January 1568, Philip II, accompanied by four councilors, went into Don Carlos' bedchamber, disarmed the Prince, and nailed up the room's windows $[1,2,12]$. Don Carlos then remained in solitary confinement until his death that occurred on 24 July 1568, 6 months after his internment. The "Leyenda Negra" (Black Legend) attributed the Prince's death to poisoning ordered by King Philip II due to the pretended jealousy from the King [6]. However, this assertion clearly lacks a solid support according to many historians and to written testimonies of witnesses of the epoch $[6,12]$. 
Fig. 1 a Prince Don Carlos as an adolescent, by Alonso Sánchez Coello (1558), Museo del Prado, Madrid. b Miniature oil painting depicting Prince Don Carlos as a child, unknown author, probably a copy of the one on the left, Museo Lázaro Galdiano, Madrid

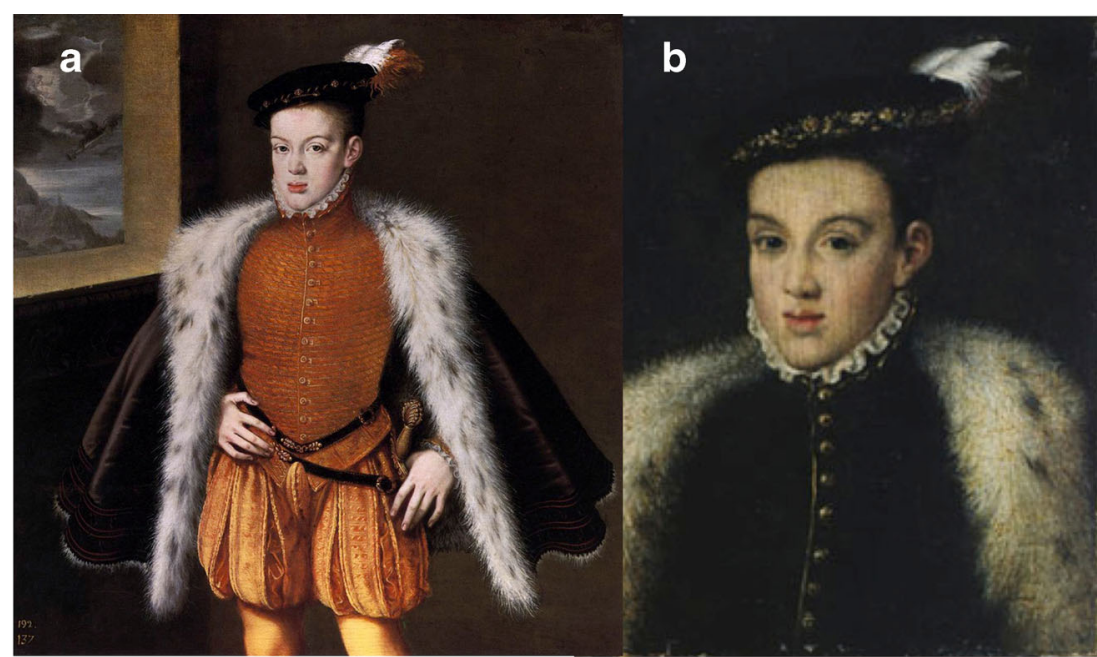

\section{On the physicians of the court of King Philip II}

In spite of King's Philip II words referring to the medical profession "physicians do not know Medicine, but no one knows it but them," he protected and respected physicians and surgeons [12]. Not less than 18 physicians belonged to the King's medical staff $[4,8,10,13]$. A study illustrates the determination of the medical profession to claim their place in the health care and describes the academic and sociocultural requirements they had to fulfill as were to be in possession of a university degree, reputable surgical experience, and the title of physician issued by the local Inquisition court [3].

Doctor Cristobal de Vega had been appointed as the chamber physician and mentor of Don Carlos since the Prince's childhood [10]. This prestigious physician had to abandon his chair at the Alcalá School of Medicine to fulfill this new task. Also, Doctor Hernandez received the King's protection and received a 4-year grant from the King to undertake a biology research in New Spain (Mexico) [13]. Olivares and Portugues also belonged to the royal physicians' staff as was the surgeon Daza Chacon $[4,10,12]$.

Andrea Vesalius, professor of anatomy at the University of Padua and author of the Fabrica, served as court physician (1537-1543) to Emperor Charles V and to King Philip II [8]. Although not belonging to the King's medical staff, he was often called in consultation. Vesalius mainly attended the military and embassy staffs and foreign ambassadors. King Philip II commended him for treating the deadly orbito-cranial injury sustained by King Henry II of France during a series of jousts to celebrate an alliance of the Spanish and French crowns [7, $8,14]$. The treatment of Henry II of France was participated by five or six of the best surgeons of France including Vesalius and Ambroise Paré, the author of the treatise "La méthode curative des playes et fractures de la teste humaine" [8].
Fig. 2 a Prince Don Carlos, oil painting attributed to Joris van der Straeten, Monasterio de las Descalzas Reales, Madrid. b Portrait of Don Carlos at approximately 19 years of age by Alonso Sánchez Coello, Kunshistrisches Museum, Wien

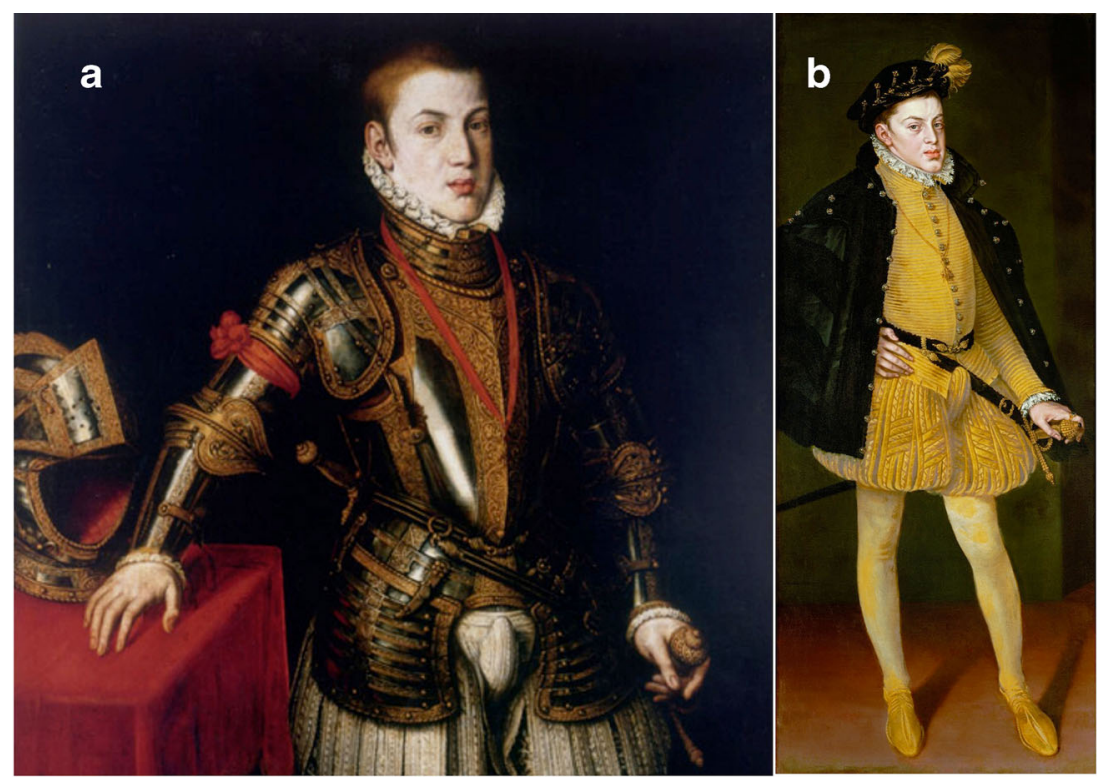


However, Don Carlos' cranial wound was the most famous case in which Vesalius took part [8].

Conflict of interest The authors declare that they have no conflict of interest and that they have not been funded for the production of this work.

\section{References}

1. Anonymous: Carlos de Austria. http://global.britannica.com/ EBchecked/topic/96409/Carlos-de-Austria. Accessed 5 Feb 2015

2. Anonymous: Carlos, Prince of Asturias. en.wikipedia.org/wiki/ Carlos_Prince_of_Asturias. Accessed 8 Feb 2015

3. Candelario JV (2008) La apropiación de un espacio asistencial por una élite professional: los médicos del Hospital Real de Granada en el siglo XVI. Asclepio 60:177-202

4. Daza Chacón D (1851) Relación verdadera de la herida de cabeza del Serenísimo Príncipe D. Carlos nuestro Señor, de gloriosa memoria, la cual se acabó en fin de Julio del año de 1562. In: Salvá M, Sainz de Baranda P (eds) Colección de documentos inéditos para la historia de España, vol 18. Viuda de Calero, Madrid, pp 537-563

5. De Zulueta J (2007) La causa de la muerte del Emperador Carlos V. Parassitologia 49:107-109

6. Edelmayer F (2011) The "Leyenda Negra" and the circulation of anti-Catholic and anti-Spanish prejudices. European History Online
(EGO). http://www.ieg-edu/edelmayer-2010-en. Accessed 26 Feb 2015

7. Faria MA Jr (1999) The death of Henry II of France. J Neurosurg 77:964-969

8. Fisch MH (1945) Vesalius in English State papers. Bull Med Libr Assoc 33:231-253

9. French H, Schaefer N, Keijzers G, Barison D, Olson S (2014) Intracranial subdural empyema. A 10-year case series. Ochsner J 14:188-194

10. Hernández J (2001) Cristóbal de Vega (1510-1573), médico de cámara del príncipe Don Carlos (1545-1568). Dynamis 21:295322

11. Olivares S (1849) Relación de enfermedad del Príncipe D. Carlos de Alcalá. In: Salvá M, Sainz de Baranda P (eds) Colección de documentos inéditos para la historia de España, vol 15. Viuda de Calero, Madrid, pp 553-574

12. Parera y Prats A (1971) Los Médicos de Felipe II y la enfermedad del Príncipe D. Carlos. An Real Acad Med (Madrid) 88:239-258

13. Shampo MA, Kyle RA (1988) Francisco Hernández, personal physician to Philip II of Spain. Mayo Clin Proc 63:742

14. Zanello M, Charlier P, Corns R, Devaux B, Berche P, Pallud J (2015) The death of Henry II, King of France (1519-1559). From myth to medical and historical fact. Acta Neurochir (Wien) 157: $145-149$

The photographs shown in this paper were obtained from the Wikipedia and are in the public domain. 